\title{
IVSIGERT's
}

IV Symposium on Agricultural and Agroindustrial Waste Management

May 5-7, 2015 - Rio de Janeiro, Brazil

\section{ASSESSMENT OF BACTERIAL AND ARCHAEAL COMMUNITY STRUCTURE IN SWINE WASTEWATER TREATMENT PROCESSES}

Da Silva, M.L.B. ${ }^{*}$; Cantão, M.E. ${ }^{1}$; Mezzari, M.P. ${ }^{2}$; Ma, J. ${ }^{3}$; Nossa, C.W. ${ }^{4}$

${ }^{1}$ EMBRAPA, BR153 Km 110 P.O. Box 21, Concórdia, SC, 89700-000 Brazil

${ }^{2}$ UNOESC, Biotechnology and Sciences Program, Videira, SC, 89560-000 Brazil

${ }^{3}$ China University of Petroleum, 18 Fuxue Rd., Beijing, 102249, China

${ }^{4}$ Department of Ecology and Evolutionary Biology, Rice University, Houston, TX, USA. ^Email: marcio.busi@embrapa.br

SUMMARY: Microbial communities from two field scale swine wastewater treatment plants (WWTPs) were assessed by pyrosequencing analyses of bacterial and archaeal $16 S$ rDNA fragments. Effluent samples from secondary [anaerobic covered lagoons and upflow anaerobic sludge blanket (UASB)] and tertiary treatment systems (open pound natural attenuation lagoon and air-sparged nitrification-denitrification tank followed by alkaline phosphorus precipitation process) were analyzed. A total of 56,807 and 48,859 high quality reads were obtained from bacterial and archaeal libraries, respectively. Dominant bacterial communities were associated with the phylum Firmicutes, Bacteroidetes, Proteobacteria or Actinobacteria. Bacteria and archaea diversity were highest in UASB effluent sample. Among the archaeal communities, $80 \%$ of the reads was related to hydrogenotrophic methanogens Methanospirillum. Enrichment of hydrogenotrophic methanogens detected in effluent samples from the anaerobic covered lagoons and UASB suggested that $\mathrm{CO}_{2}$ reduction with $\mathrm{H}_{2}$ was the dominant methanogenic pathway in these systems. Overall, the results served to improve our current understanding of major microbial communities' changes downgradient from the pen and throughout swine WWTP as result of different treatment processes.

Keywords: Archaeal, bacterial, pyrosequencing, swine wastewater.

\section{INTRODUCTION}

Brazil is the sixth largest swine meat consumer $\left(15 \mathrm{~kg} \mathrm{yr}^{-1}\right.$ person $\left.{ }^{-1}\right)$ and the fourth largest exporter (0.52 Mt $\mathrm{yr}^{-1}$ ) in the world (ABIPECS, 2011). The increase in swine agribusiness activities is accompanied by larger volumes of wastewater that requires adequate treatment prior to land application and/ or discharge into water bodies. Among the swine wastewater treatment processes known, anaerobic biodigesters followed by open pound storage lagoons are widely used (Viancelli et al., 2013).

Molecular biology tools have been used to characterize microbial communities present in swine wastewater lagoons, pit storage and anaerobic biodigesters (Kim et al., 2010). These, studies contribute to valuable information about WWTPs biological system performance and efficiency. Moreover, these studies can elucidate the effects that each particular treatment may exert on microorganism's selective pressure and growth of specific strains which could be detrimental to water quality and biosafety (Jeong et al., 2011). The latter is especially important when considering the significantly high water demands employed (ranging from 0.63 to 3.63 gallons pig space ${ }^{-1}$ day $^{-1}$ ) and the emerging needs for water reuse (Viancelli et al., 2013). Nonetheless, little is known about the microbial population shifts that are likely to occur downgradient from the swine pens throughout the different treatment processes.

Therefore, the objective of this work was to investigate the microbial communities present in the effluent samples from two independent field-scale swine WWTPs. The structure of both bacterial and archaeal communities encountered on the pen floor sediment and effluents from anaerobic covered lagoons, open pond storage lagoon, UASB and air-sparging denitrification system followed by phosphorus alkaline 


\section{IVSIGERT's}

IV Symposium on Agricultural and Agroindustrial Waste Management

May 5-7, 2015 - Rio de Janeiro, Brazil

precipitation were assessed by high-throughput pyrosequencing analyses of $16 \mathrm{~S}$ rDNA fragments.

\section{MATERIAL AND METHODS}

Bacterial and archaeal communities were sampled from different swine wastewater treatment plants: WWTP1 and WWTP2. Samples from WWTP1 were collected from two anaerobic covered lagoons connected in series (designated as bio1 and 2, respectively) and the final effluent. Samples from WWTP2 were collected from the pen, the UASB reactor and the final effluent. Genomic DNA was extracted using MoBio UltraClean $\AA$ kit for the liquid or PowerSoilß kit (Carlsbad, CA, US) for sediment samples according to the manufacturer's protocol. Pyrosequencing of the 16S rDNA region was performed with primers for bacterial 16S and for archaeal 16S according to Nossa et al. (2010). All 16S rDNA pyrosequencing reads were analyzed using the original standard flowgram format (SFF) output file from the sequencer in Mothur, version 1.32.1 following the 454 standard operating process (Schloss et al., 2009). Sequence alignment was performed in Mothur using SILVA database (release 111) clustered at $97 \%$ similarity as reference (Caporaso et al. 2010).

\section{RESULTS AND DISCUSSION}

A total of 56,807 and 48,859 high quality sequence reads were obtained from bacterial and archaeal $16 S$ rDNA, respectively. Among the samples evaluated, the effluent sample from the UASB at WWTP 2, showed the highest number of bacteria OTUs (2,015 at $97 \%$ similarity, or 660 if normalized sequences). However, the highest number of archaea OTUs (56 or 31 if normalized sequences) was observed in the effluent sample from bio1 at the WWTP 1. Bacterial diversity from highest to lowest was UASB > final effluent from WWTP $2>$ pen floor > effluent from bio1 > final effluent from WWTP $1>$ effluent from bio2. The increased bacterial diversity observed in the UASB effluent sample could be explained by the reactor intrinsic characteristic that stimulates the growth of different microorganism's communities living in syntrophic association in suspended cell granules as biofilms (Chong et al., 2012). Bacterial communities were mostly associated with phylum Firmicutes, Bacteroidetes, Proteobacteria or Actinobacteria. Negligible bacteria phylogenetic distances $(p<0.01)$ were verified among the pen floor (at WWTP 2) and all effluent samples analyzed from WWTP 1 . These results served as circumstantial evidence to support that both WWTPs had similar bacteria diversity entering in the systems as inoculum. Significant discrepancy in bacteria phylogenetic distances $(p<0.01)$ was only verified for the sample collected at the UASB effluent at WWTP 2.

The methanogenic enrichment was related to (\% of the total 16S rDNA relative abundance) Methanospirillum, Methanogenium, Methanobrevibacter, Methanocorpusculum, Methanosarcina, and Methanoculleus (Figure 2). Methanosarcina population was higher in UASB effluent sample as compared to anaerobic covered lagoons (bio1 and bio2) effluent samples. Members of this genus are metabolically very versatile and capable of producing methane from all three known pathways i.e., hydrogenotrhophic, acetoclastic and methylotrophic. Methane production in the anaerobic biodigesters from both WWTPs was predominantly associated with the reduction of CO2 with $\mathrm{H} 2$ by hydrogenotrophic methanogens. 


\section{IVSIGERT's}

IV Symposium on Agricultural and Agroindustrial Waste Management

May 5-7, 2015 - Rio de Janeiro, Brazil

\section{CONCLUSIONS}

Bacterial and archaeal 16S rDNA pyrosequencing analyses performed in effluent samples from two independent and full scale swine wastewater treatment plants served to improve our current understanding on microbiology at these systems. Bacteria and archaea diversities were significantly higher in UASB effluent sample. Among the identified archaea, hydrogenothrophic Methanoculleus and Methanocorpusculum were only observed in UASB effluent sample. The relative abundance of Methanosarcina was also notably much higher in the UASB effluent as compared to the anaerobic covered lagoons. The increased abundance of hydrogenotrophic methanogens ( $>80 \%$ of the $16 \mathrm{~S}$ rDNA relative abundance) provides fundamental information to support that methane production in swine anaerobic biodigesters is largely dependent on $\mathrm{CO}_{2}$ reduction with $\mathrm{H}_{2}$ in these anaerobic systems.

\section{ACKNOWLEDGEMENT}

This research was supported by the Brazilian Agricultural Research Corporation (EMBRAPA) grant \# 01.11.07.002.05.00.

\section{REFERENCES}

ABIPECS (2011) Annual Report. Associacao Brasileira da Industria Produtora e Exportadora de Carne Suina. http://www.abipecs.org.br/uploads/relatorios/relatoriosassociados-ingles/Abipecs_annual_report_2011.pdf. Accessed 07 July 2014

Caporaso JG, Kuczynski J, Stombaugh J, Bittinger K, Bushman FD, Costello EK, Fierer N, Pena AG, Goodrich JK, Gordon JI, Huttley GA, Kelley ST, Knights D, Koenig JE, Ley RE, Lozupone CA, McDonald D, Muegge BD, Pirrung M, Reeder J, Sevinsky JR, Turnbaugh PJ, Walters WA, Widmann J, Yatsunenko T, Zaneveld J, Knight R (2010) QIIME allows analysis of high-throughput community sequencing data. Nature methods 7: 335-336.

Chong S, Sen TK, Kayaalp A, Ang HM (2012) The performance enhancements of upflow anaerobic sludge blanket (UASB) reactors for domestic sludge treatment - A State-of-theart review. Water research 46: 3434-3470.

Jeong JY, Park HD, Lee KH, Weon HY, Ka JO (2011) Microbial community analysis and identification of alternative host-specific fecal indicators in fecal and river water samples using pyrosequencing. Journal of microbiology (Seoul, Korea) 49: 585-594.

Kim W, Lee S, Shin SG, Lee C, Hwang K, Hwang S (2010) Methanogenic community shift in anaerobic batch digesters treating swine wastewater. Water research 44: 4900-4907.

Nossa CW, Oberdorf WE, Yang L, Aas JA, Paster BJ, Desantis TZ, Brodie EL, Malamud D, Poles MA, Pei Z (2010) Design of 16S rRNA gene primers for 454 pyrosequencing of the human foregut microbiome. World journal of gastroenterology : WJG 16: 4135-4144.

Schloss PD, Westcott SL, Ryabin T, Hall JR, Hartmann M, Hollister EB, Lesniewski RA, Oakley BB, Parks DH, Robinson CJ, Sahl JW, Stres B, Thallinger GG, Van Horn DJ, Weber CF (2009) Introducing mothur: open-source, platform-independent, communitysupported software for describing and comparing microbial communities. Appl Environ Microbiol 75: 7537-7541.

Viancelli A, Kunz A, Steinmetz RLR, Kich JD, Souza CK, Canal CW, Coldebella A, Esteves PA, Barardi CRM (2013) Performance of two swine manure treatment systems on chemical composition and on the reduction of pathogens. Chemosphere 90: 15391544. 


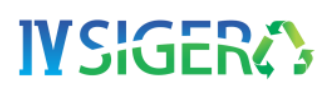

IV Symposium on Agricultural and Agroindustrial Waste Management

May 5-7, 2015 - Rio de Janeiro, Brazil

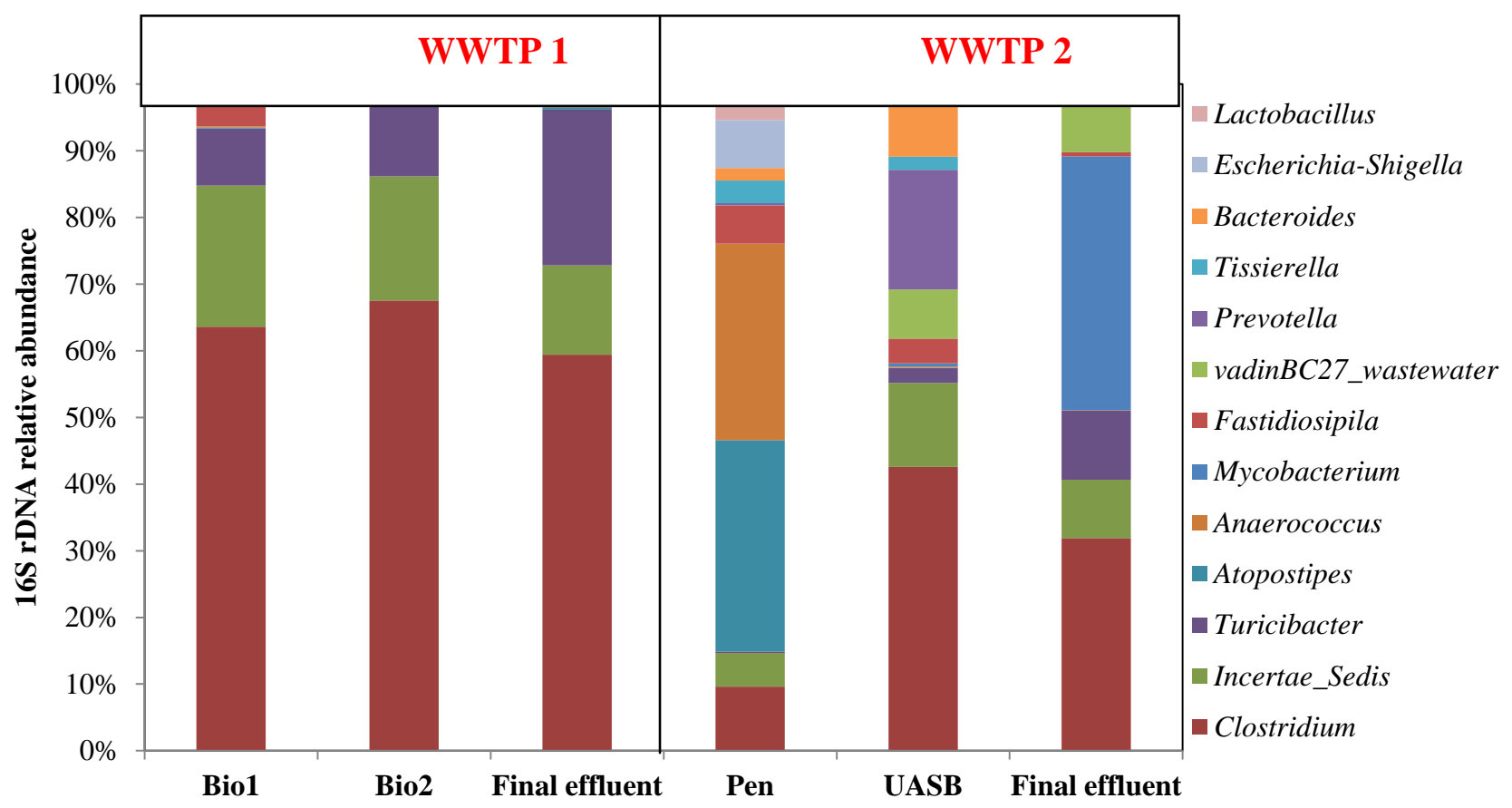

Figure 1. The relative abundance of bacterial $16 \mathrm{~S}$ rDNA genes found in sediment from the pen floor and effluent samples from two independent WWTPs.

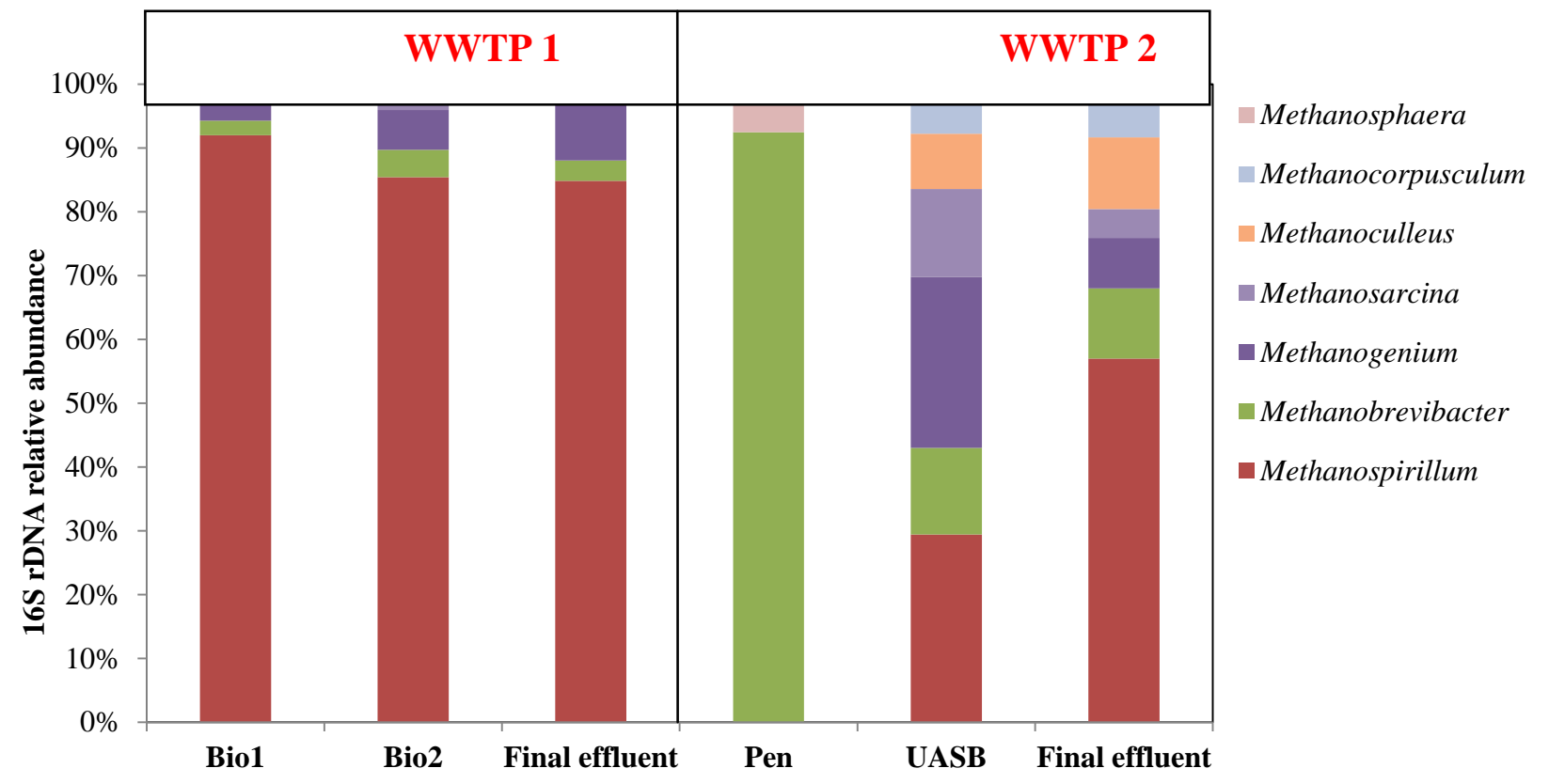

Figure 2. The relative abundance of archaeal $16 \mathrm{~S}$ rDNA genes found in sediment from the pen floor and effluent samples from two independent WWTPs. 